\title{
One Cannot Promote Free Movement of EU Citizens and Restrict Their Political Participation
}

\author{
Dora Kostakopoulou
}

The contributions to the EUDO debate on whether EU citizens should have voting rights in national elections in the country of their residence are both enlightening and thoughtful. They have provided a number of valuable reflections on matters of principle, policy, strategy, and tactics in the light of contemporary political developments at both European Union and domestic levels. By clarifying matters of principle as well as issues of politics, they have outlined several trajectories and shed ample light onto the pros and cons of the European Citizens' Initiative.

Given the horizon of possibilities open to us, we are now obliged to exercise our liberty to decide whether we would support the proposal for a European Citizens' Initiative on national voting rights. Let me state at the outset that I fully support it; after all, since the mid-1990s my work has consistently defended the grant of electoral rights in national elections to European Union citizens in the member state of residence. Believing that circumstances do not decide (and should not decide) and that deciding not to decide is not a credible option, the above line of decision has been prompted by the following four considerations.

\section{1) The weight of principles}

The contradiction between belonging fully to a polity as a contributor, collaborator, and burden-sharer and at the same time being deemed as not fully belonging to it with respect to the enjoyment of certain benefits, including national voting rights, is unsustainable form a democratic point of view. Robert Dahl and Carlos Santiago Nino have convincingly pointed out that democracy requires inclusion and, most certainly, the inclusion of all those who have a long-term interest in a country and its institutions. In this respect, the full enfranchisement of Union citizens in the member state of their residence is the only corrective to the existing 'democratic wrong', as Owen has put it.

True, some might argue, here, that admission of Union citizens to the 'national community' of citizens would undermine the distinction between 
nationals and aliens and dilute the national character of parliamentary elections. Others might be quick to point out here that such a reform might undermine national interests. Although such objections are reasonable from the standpoint of liberal nationalism, they need reassessment in light of the current state of European integration and the fundamental status of European Union citizenship. For in the eyes of European as well as national laws, Community nationals are neither 'aliens' nor 'strangers'; they are, instead, Union citizens endowed with a number of rights that the member states must affirm. The Citizenship Directive (2004/38) has recognised this and has strengthened Union citizenship by establishing an unconditional right of permanent residence for Union citizens and their families who have resided in a host member state for a continuous period of five years. Accordingly, limiting the political rights of permanent resident Union citizens, who are already members of the demos at the local level and permanent members of the community, hinders democratic participation by depriving them of an effective voice in the legislative arena.

In addition, as the American philosopher John Dewey has pointed out, 'democracy is more than a form of government; it is primarily a mode of associated living, of conjoint communicated experience' ${ }^{1}$. And this experience becomes dwarfed when national voting rights become a good reserved for co-nationals while EU citizens who are long-term residents are relegated to the status of the subject. They look at their everyday lives and the levels of the contribution, the homes they have created and the homes they have abandoned in the member state of origin and cannot understand why they should be viewed as 'guests' or foreigners' in the community they call 'their own' and the country they have 'chosen' to make the hub of their lives. With the passage of time, their voices, initially inarticulate and gentle, are bound to become more noisy as they see their taxes diverted into policy choices for which they have had not even a simple invitation to express an opinion for.

Once the weight of principles is appraised, the space of ordinary experience and expectation is surveyed and measured and the rationale of European integration of creating true associates by making the tag of nationality irrelevant when decisions about how people should be treated are made is given the importance it deserves, then the proposed idea of extending political rights to national parliamentary elections in the member state of residence does not give rise to a difficult dilemma.

1 Dewey, J. (1964[1916]), Democracy and Education. New York: Macmillan, 87. 


\section{2) Tackling the democratic deficit without the methodological privileging of the state}

Once the democratic deficit is acknowledged, questions of how best to correct it come into play. These questions, and their answers, have been discussed very eloquently by the contributors to this debate. The options on the table include the horizontal opening of national citizenship or the extension of Union citizenship. By opting for the former, we implicitly recognise (i) that it is the member states' business to correct the wrong; (ii) the national character of domestic citizenship should be preserved, and iii) that naturalisation should be the means of full participation in the national as well as European demoi. All three assumptions, however, clearly privilege the state and, by so doing, conceal the fact that the national state is called upon to resolve a wrong that its own constituent organising ideas have created in the first place. All three assumptions also superimpose two different logics and realities; namely, the logic of non-discrimination on the grounds of nationality and thus equalisation (full equality of treatment irrespective of nationality throughout the EU) (the logic of equality) and the national statist logic of turning aliens into nationals via naturalisation along with the underpinning rationale of cultural homogenisation in some form or another (the nationcentric logic). However, these logics are very different and must be kept apart. Certainly, European integration has been premised on nondiscrimination and to assume that the state and its (national) ways should be given a theoretical and methodological priority with respect to the future development of EU citizenship denotes an ideological point of view. After all, why should not the citizens' everyday lives, lived encounters and expectations matter as much as states' interests in perpetuating the national citizenship narratives? And why should not the fundamental status of European Union citizenship place itself inside states' political domain and affirm its right to existence?

True, electorates in the member states may not welcome the extension of EU citizenship to national parliamentary elections. They may react negatively and right-wing extremism might capitalise on it in order to mobilise people against the governing political elites and the EU. But this is something that can happen anyway with respect to any real or imagined policy reform. Can political imagination and socio-political change remain captive of conservative interests which seem to fix their gaze firmly on the past and on the artificial commonalities of race, ethnicity, language and national culture thereby underscoring not only commonalities of interests, commitment to a shared institutional framework and of shared collective practices, but also the boundary crossings that preceded all the above commonalities, 
both real and imagined, and the crossings that take place continuously around us? Can we afford to become the subterfuge of a historical process that robs us of judgment?

\section{3) The road travelled thus far}

Having to decide which trajectory to follow with respect to voting rights in national elections and to reflect on the concerns outlined by the contributors to this debate is not without precedent. It is important to remember that in the 1970s and 1980s the same debate took place with respect the so-called 'special rights', which included the right of Community nationals to vote and to stand as a candidate in local elections in the member state of residence. 'Equal treatment of Union citizens in the political field', 'strengthening the feeling of belonging to one legal community', 'complete assimilation with nationals as regards political rights', 'creating a people's Europe' and 'responding the expectations of Community nationals' were the rationales underpinning the grant of local electoral rights to EU citizens without a prior activation of national naturalisation procedures. Brave thinking at that time captured the dilemmas, weighed member states' concerns and, following such reflections and negotiations, the option that was favoured was 'special rights' rather than naturalisation because it was important that Community nationals were treated in host member states as if they were citizens of those states. Promoting greater equality with nationals was more beneficial than the opening up of the naturalisation gates because 'the emphasis should remain on residence rather than nationality. ${ }^{2}$

And in the mid-1970s, national electorates' opposition to such an idea was considered, too. As the Commission stated at that time, 'equal treatment of foreigners in the economic and social fields is accepted by public opinion, since this has long been a subject for frequent negotiation between States, the same does not apply to equal treatment of foreigners in the political field. This is a new idea and the public will have to be given an opportunity to get used to it.'

Additionally, when the Treaty on European Union entered into force, several MS continued to resist the implementation of what was then Article $8 b(E C)$. In fact, by January 1997 of the fifteen member states only eight had made the grant of local electoral rights for EU citizens a reality. Fears of

2 Commission of the European Communities (1975), Towards European Citizenship, Bull. EC, Supplement 7, 32.

3 Commission of the European Communities (1975), Towards European Citizenship, 30 
diluting local elections, fears of challenging the primacy of national citizenship, fears of making the European Union a tangible reality and thus contributing to the sidelining of member states were expressed frequently in the public domain, but none of these fears really materialised.

The memory of what has taken place and of the institutional choices on offer in the 1970s, 1980s, and early 1990s is thus a decisive one at this moment. For if turn our gaze from the current initiative toward the past, we can easily gain a glimpse of the solution. I would argue that this solution has created a path dependence which would make any other policy choice with respect to national electoral franchise a deviation and thus requiring a clear justification. The proposed Citizens' initiative thus creates a turning point as far as the maturation of EU citizenship is concerned. The questioning of the idea that political domains should be reserved for states' own nationals is unfolding. And in the same way that the European Community was not afraid to open local political spaces to non-national citizens of other member states in the past, the time has come for the completion of this process and the realisation of equality of treatment by fully enfranchising EU citizens automatically in the member state of their residence.

\section{4) Free movement and EU citizenship are not only about spacing; they are also about timing}

It is true that in both the literature on free movement of persons and the relevant case law spatial matters relating to cross-border are the main focus. Changes of location, border crossings and settlement in another member states activate most (albeit not all) of the advantages that EU law offers to EU citizens. What is completely disregarded in all these 'travelogues' is that exercising EU citizenship rights is also a temporal movement: a movement of 'before' crossing a border and 'after'; a shift from one collective imaginary and personal world to another collective imaginary and new personal world to be constructed; a change in perspective, viewpoint and system of beliefs; and the enjoyment of a sense of freedom and the daring opening of oneself to different rhythms of individual history and social surroundings. In this temporal movement change unavoidably takes concrete manifestation in the form of the appearance of new interpretations of the social environment, a new frame of mind, new questions, new dilemmas and eventually new answers. Member states cannot afford to bracket this temporal movement that shapes the lives of their new residents and their 'mutating' individuality either by continuing to subsume them under the fixed categories of home nationalities or by placing them into static and unchanging statuses. For the meanings, interpretations, ideas, interests, expectations and 
meaningful relations that surround the life of EU citizens are not merely embodied in space; they also unfold in time.

Domestic political domains thus need to acknowledge that a new predicament brings about a receding past, decaying relations and entanglements in the light of new experiences, a new sense of worldliness, new entanglements, new personal journeys, new meaningful relations, new events and new political exigencies requiring responses. The temporal movement characterising settlement in a new environment is not only a process, but is also a variation, that is, change. Accordingly, democratic public spheres must be open to new participants and should be engagement promoters. Similarly, European Union institutions cannot afford to disregard this temporal movement, for they have been instrumental in lifting EU citizens from the imaginary of rooted publics and imparting onto them a sense of freedom and the consciousness of being treated with dignity and equality wherever they go in the territory of the Union. After all, this is what European integration was hoped to be able to accomplish since its early stages.

Arguably, it would be a fundamental contradiction, if, one the one hand, EU citizens were encouraged to move, cultivate new allegiances, form new orientations, have a European consciousness, create new realities, to be part of the fabric of the host societies and be treated as equal collaborators and participants, while European institutions, including the Council of the EU, refused to accept the full consequences, which include that EU citizens would feel themselves as active collaborators and participants in society and politics, on the other. Shutting the gate of political participation in national elections and frustrating the legitimate democratic aspirations of all those who for one reason or another partook of the European project and became valued members of the community of their residence would be tantamount to condemning one of the biggest achievements of the European integration project and making the proclamation to encourage participation in the democratic life of the Union empty rhetoric.

\section{Legal norms should reflect social practices and EU citizens' lived encounters}

Legal norms cannot afford to disregard both principles and social practices. If they do, they will eventually lose credibility. The partial franchise of EU citizens is clearly not adequate. Nor does it provide a frank solution for the future. Its extension to national parliamentary elections is thus necessary and this can only be done by resisting the temptation to shut ourselves up in the present and apply the 'available', that is, some stretching or opening up 
of national citizenship, but by deciding a clear announcement of the future, that is, by removing the existing restrictions in the application of the principle of equal treatment and by making national electoral participation available to all those EU citizens who are enmeshed in the member states of their residence and have been sharing their burdens without any complaints for so many years.

Open Access This chapter is licensed under the terms of the Creative Commons Attribution 4.0 International License (http://creativecommons.org/licenses/by/4.0/), which permits use, sharing, adaptation, distribution and reproduction in any medium or format, as long as you give appropriate credit to the original author(s) and the source, provide a link to the Creative Commons license and indicate if changes were made.

The images or other third party material in this chapter are included in the chapter's Creative Commons license, unless indicated otherwise in a credit line to the material. If material is not included in the chapter's Creative Commons license and your intended use is not permitted by statutory regulation or exceeds the permitted use, you will need to obtain permission directly from the copyright holder.

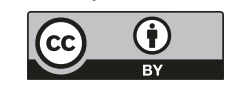

